\title{
USE OF THE POLYMERASE CHAIN REACTION FOR THE DIAGNOSIS OF ASYMPTOMATIC Leishmania INFECTION IN A VISCERAL LEISHMANIASIS-ENDEMIC AREA
}

Luciana Almeida SILVA(1), Héctor Dardo ROMERO(1), Aline FAGUNDES(2), Nédia NEHME(2), Otávio FERNANDES(3), Virmondes RODRIGUES(1), Roberto Teodoro COSTA(4)* \& Aluízio PRATA(1)*

\begin{abstract}
SUMMARY
The diagnosis of asymptomatic infection with Leishmania (Leishmania) chagasi has become more important over recent years. Expansion of visceral leishmaniasis might be associated with other routes of transmission such as transfusion, congenital or even vector transmission, and subjects with asymptomatic infection are potential reservoirs. Moreover, the identification of infection may contribute to the management of patients with immunosuppressive conditions (HIV, transplants, use of immunomodulators) and to the assessment of the effectiveness of control measures. In this study, 149 subjects living in a visceral leishmaniasis endemic area were evaluated clinically and submitted to genus-specific polymerase chain reaction (PCR), serological testing, and the Montenegro skin test. Forty-nine (32.9\%) of the subjects had a positive PCR result and none of them developed the disease within a follow-up period of three years. No association was observed between the results of PCR, serological and skin tests. A positive PCR result in subjects from the endemic area did not indicate a risk of progression to visceral leishmaniasis and was not associated with a positive result in the serological tests.
\end{abstract}

KEYWORDS: Visceral leishmaniasis; Asymptomatic; Diagnosis; Polymerase chain reaction.

\section{INTRODUCTION}

Molecular biology techniques are used increasingly for the diagnosis of different forms of leishmaniasis. Peripheral blood-based polymerase chain reaction (PCR) assays can be applied to the diagnosis of human visceral leishmaniasis (VL), but better results have been obtained with bone marrow or spleen aspirates. Studies have reported variable sensitivity and specificity of this technique, reaching almost $100 \%$ for the diagnosis

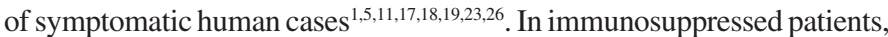
particularly those with acquired immunodeficiency syndrome (AIDS), the diagnosis of human VL by serological methods has yielded unsatisfactory results and PCR has been proposed as a good alternative $\mathrm{e}^{10,12,20}$.

Although the existence of subjects suffering from asymptomatic Leishmania infection has been recognized, it is difficult to prove. The methods commonly used for identification of the parasite are not justified in asymptomatic cases because of the risks or discomfort to the individual. Immunological tests are widely used for the diagnosis of subclinical kala-azar, but there is no consensus regarding the interpretation of the results $^{22,25}$. In this respect, PCR also serves to identify subjects with a positive test for human VL who live in endemic areas and show no signs or symptoms of the disease $e^{9,23,27}$.

The objective of the present study was to evaluate the evolution of subjects living in a VL-endemic area who have positive PCR results for Leishmania in peripheral blood.

\section{PATIENTS AND METHODS}

Patients: The study was conducted in the Municipality of Porteirinha, a northern region of the state of Minas Gerais, Brazil. This area is endemic for VL and cases of tegumentary leishmaniasis are rare.

In 1998, a total of 1,241 residents of this endemic area were submitted to anamnesis, clinical examination, and blood collection for serological testing. These subjects also underwent delayed hypersensitivity testing (Montenegro skin test, MST) ${ }^{22}$. In addition, peripheral blood was collected from a portion of this population $(n=149)$ for genus-specific PCR.

The subjects of the study were reassessed clinically 3-4 years after the first collection in order to identify signs and symptoms suggestive of VL (e.g., fever, hepatosplenomegaly, pallor, and pancytopenia). In addition to clinical reassessment, the serological tests and MST were repeated in 68 of the 149 subjects for whom PCR results were available (31 with a negative result and 37 with a positive result).

Informed consent was obtained from all participants and the project

*In Memoria

(1) Universidade Federal do Triângulo Mineiro. E-mail: 1almeidas@dcm.uftm.edu.br; hdardo_r_f@hotmail.com; vrodrigues@ reitoria.uftm.edu.br

(2) Fundação Oswaldo Cruz, Rio de Janeiro, Laboratório de Vigilância em Leishmaniose. E-mail: aline.fagundes@ipec.fiocruz.br; nedianr@ioc.fiocruz.br

(3) Fundação Oswaldo Cruz, Rio de Janeiro - Laboratório de Epidemiologia Molecular de Doenças Infecciosas. E-mail: otaviofernandes@ fiocruz.br

(4) Universidade Federal de Minas Gerais, Instituto de Ciências Biológicas.

Correspondence to: Luciana Almeida Silva. Universidade Federal do Triângulo Mineiro. E-mail: lalmeidas@dcm.uftm.edu.br 


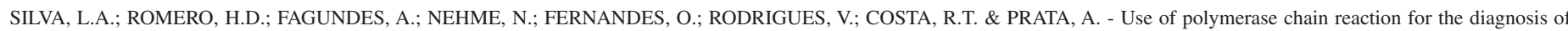
asymptomatic Leishmania infection in a visceral leishmaniasis-endemic area. Rev. Inst. Med. Trop. Sao Paulo, 55(2): 101-4, 2013.

was approved by the Board of UFTM (Resolution 196/96 of the National Research Council, Brazilian Ministry of Health).

Polymerase chain reaction: The PCR assays were carried out at Fiocruz, Rio de Janeiro. For DNA extraction, $5 \mathrm{~mL}$ blood collected in EDTA was centrifuged at $4000 \mathrm{rpm}$ for $10 \mathrm{~min}$ and the buffy coat (leukocyte concentrate) was collected and transferred to a $1.5 \mathrm{~mL}$ microtube. DNA was extracted from this material using the Rapid Prep Micro Genomic DNA Isolation kit. The nucleic acid eluted in $100 \mu \mathrm{L}$ elution buffer was precipitated by adding $1 / 10$ volume of sodium acetate and 2.5 volumes of absolute ethanol. This mixture was centrifuged at $13,000 \mathrm{rpm}$. The sediment was washed in $70 \%$ ethanol and resuspended in $20 \mu \mathrm{L}$ reagent water.

The PCR mixture contained $200 \mu \mathrm{M}$ dNTPs, $0.5 \mathrm{U}$ Taq DNA polymerase in buffer recommended by the manufacturer, $100 \mathrm{ng}$ of each primer, $2 \mu \mathrm{L}$ DNA extracted from the leukocyte concentrate, and 1.5 $\mathrm{mM} \mathrm{MgCl}{ }_{2}$, in a final volume of $50 \mu \mathrm{L}$. Primers targeting the periphery of a conserved region of the minicircles of the mitochondrial genome, which amplify a fragment of $120 \mathrm{bp}$, were used (forward: 5' GGG GAG GGG CGT TCT GCG AA; reverse: 5'CCG CCC CTA TTT TAC ACC AAC CCC and 5' GGC CCA CTA TAT TAC ACC AAC CCC). Positive controls containing $50 \mathrm{ng}$ genomic DNA of $L$. brasiliensis and negative controls (no addition of DNA) were included in each PCR assay. The amplification conditions were 30 cycles at $94{ }^{\circ} \mathrm{C}$ for $30 \mathrm{~s}, 50{ }^{\circ} \mathrm{C}$ for 30 $\mathrm{s}$, and $72{ }^{\circ} \mathrm{C}$ for $30 \mathrm{~s}$.

The PCR products $(10 \mu \mathrm{L})$ were analyzed by $2 \%$ agarose gel electrophoresis in Tris-borate-EDTA buffer in a horizontal unit. The gels were stained with ethidium bromide and bands were visualized under ultraviolet light. Reactions presenting a band of $120 \mathrm{bp}$ were classified as positive.

Serological tests and Montenegro skin test: The following serological tests and MST as described by ROMERO et al. (2009) and SILVA et al. (2011) were used: enzyme-linked immunosorbent assay (ELISA) and indirect immunofluorescence test (IIFT) using Leishmania (Leishmania) amazonensis promastigote antigen, ELISA using recombinant K39 (ELISA rK39) and K26 (ELISA rK26) antigens, and immunochromatographic test using rK39 antigen (TRALd) ${ }^{22,25}$.

Statistical analysis: A positive result in each diagnostic test was compared between the first and second evaluation by the McNemar test. Optical densities were compared between the two groups by the MannWhitney test. Agreement between the diagnostic tests was evaluated by the kappa coefficient. Statistical analysis was performed using the Statistica 8.0 software (Statsoft, Inc., Tulsa, OK). A $p$ value $<0.05$ was considered to be significant.

\section{RESULTS}

Among the 149 subjects submitted to PCR, 112 (75.2\%) reported no contact with cases of human VL, $32(21.5 \%)$ had had contact at home with patients with VL for some time, and five $(3.3 \%)$ had a history of treatment of human VL. PCR was positive in 49 (32.9\%) of these subjects and negative in $100(67.1 \%)$. Although the frequency of a positive PCR result was higher among subjects who had contact with human VL, the difference was not statistically significant (Table 1 ). With respect to subjects with a history of VL treatment, blood was collected from all of them at least six months after the end of treatment. The interval between VL treatment and blood collection for PCR was six months, seven months and five years for the three cases with a positive PCR result, and 10 months and seven years for those with a negative PCR result.

Table 1

Result of PCR according to epidemiological history

\begin{tabular}{lccc}
\hline & $\begin{array}{c}\text { Positive } \\
\text { PCR }\end{array}$ & $\begin{array}{c}\text { Negative } \\
\text { PCR }\end{array}$ & Total \\
\hline Endemic area & 32 & 80 & 112 \\
Endemic area + contact with VL & 14 & 18 & 32 \\
History of VL & 3 & 2 & 5 \\
\hline Total & 49 & 100 & 149 \\
\hline
\end{tabular}

VL: human visceral leishmaniasis. $p>0.05$.

No significant differences in the frequency of positive serological tests or a positive MST were observed between subjects with a positive and negative PCR result (Fig. 1).

In the first assessment, no association was found between the serological or MST results and PCR $(p>0.05)$. In addition, the kappa coefficient was $\leq 0.1$ in all cases (Table 2). Clinical reassessment after
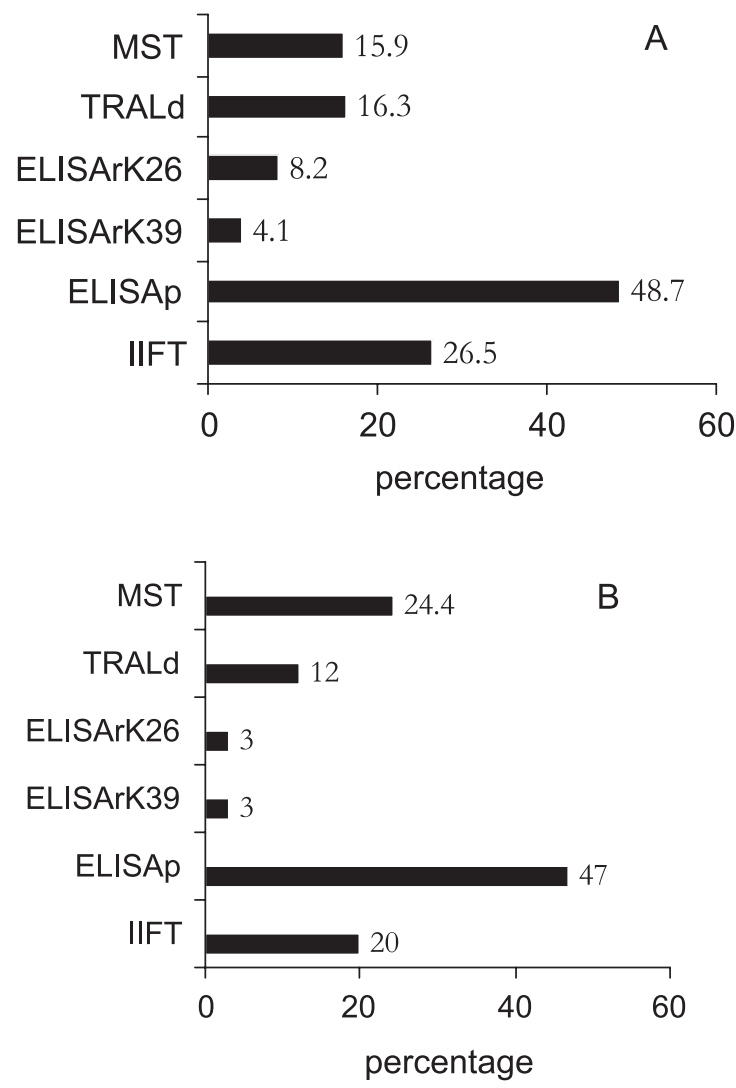

Fig. 1 - A) Frequency of positive serological tests in subjects with a positive PCR result. B) Frequency of positive serological tests in subjects with a negative PCR result. 


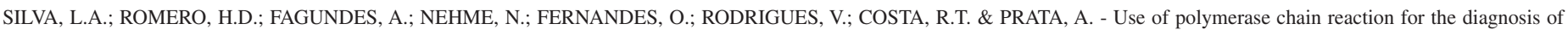
asymptomatic Leishmania infection in a visceral leishmaniasis-endemic area. Rev. Inst. Med. Trop. Sao Paulo, 55(2): 101-4, 2013.

three to four years showed that none of the PCR-positive subjects had developed VL. In the case of the 68 subjects who were submitted to repeat serological testing and MST, again no significant difference was found in the percentage of positive serological tests between subjects with a previously positive and negative PCR result. Agreement between methods continued to be low (kappa $\leq 1)$ and no association was observed between the results of PCR and serological testing $(p>0.05)$.

Table 2

Kappa agreement between PCR and the serological tests used for the diagnosis of asymptomatic infection

\begin{tabular}{lc}
\hline & Kappa coefficient \\
\hline PCR x TRALd & 0.08 \\
PCR x IIFT & 0.10 \\
PCR x ELISAp & -0.02 \\
PCR x ELISA rK39 & -0.06 \\
PCR x ELISA rK26 & 0.08 \\
PCR x MST & -0.09 \\
\hline
\end{tabular}

\section{DISCUSSION}

The identification of asymptomatic carriers of Leishmania in VL-endemic areas is becoming increasingly important for different reasons, including the possibility to evaluate asymptomatic subjects as potential reservoirs of the parasite, to determine the effectiveness of control measures, and to evaluate the risk of transmission through blood donation or vertical transmission. In addition, cases that may develop the disease, especially among immunodepressed patients, can be identified early ${ }^{14}$. However, the diagnosis of asymptomatic infection continues to be a challenge in epidemiological studies. The methods most frequently used for this purpose are serological tests, MST, and PCR. Asymptomatic subjects from endemic areas with a positive result in any of these tests have been considered to be carriers of subclinical kala-azar ${ }^{2,4,7,8,13}$.

The hypothesis of the present study was that the prospective evaluation of subjects with a positive PCR result for Leishmania would identify those who develop the disease, which was not the case. Therefore, no subject was identified during the incubation period of VL. In addition, an association was expected between the results of serology and PCR, with simultaneous positivity of asymptomatic cases and conversion of the MST in initially positive subjects over time. However, low agreement between the results of PCR and serological testing was observed in all assessments. Furthermore, monitoring of the frequency of MST conversion showed no difference between PCR-positive and -negative subjects.

In light of this, the presence of subjects with a positive immunochromatographic test, a frequent bedside test that shows good diagnostic performance for classical cases of VL, should be emphasized ${ }^{3}$. In the present study, subjects with a positive TRALd did not develop the disease, irrespective of the PCR result, as observed in other studies ${ }^{15,16}$.

In the group treated for VL, a positive PCR result was observed in three subjects six months or more after the end of treatment. Interestingly, one patient presented a positive blood PCR result five years after the end of treatment. This finding suggests the persistence of the parasite even after specific treatment, in agreement with the literature ${ }^{21,24}$.

One limitation of the present study was the exclusive use of genusspecific PCR. Although subjects from a VL-endemic area where cases of tegumentary leishmaniasis are rare were studied, the possibility that PCR-positive subjects were infected with some dermatotropic Leishmania species cannot be ruled out. Other trypanosomatids, such as Trypanosoma cruzi, can also show cross-reactivity in the PCR assay.

The present findings are consistent with other investigations and highlight the difficulty in choosing a test for the diagnosis of asymptomatic Leishmania infection ${ }^{16}$. The low agreement between the results of serology and PCR has been attributed to the higher sensitivity of PCR since this method evaluates the direct presence of parasite DNA ${ }^{6,15}$. In contrast, other authors argue that the low experience with Leishmania primers may lead to false-positive results 5 .

In conclusion, in the present study a positive genus-specific PCR in subjects from an endemic area did not indicate a risk of progression to VL and was not associated with the results of serology or MST. Further studies are needed to determine the best diagnostic method for asymptomatic Leishmania infection in VL-endemic areas and to define its true role in the expansion of the disease into urban areas.

\section{RESUMO}

\section{Uso da reação em cadeia da polimerase para o diagnóstico de infecção assintomática por Leishmania em área endêmica de leishmaniose visceral}

O diagnóstico de infecção assintomática por Leishmania (Leishmania) chagasi tem assumido crescente importância nos últimos anos. A expansão da leishmaniose visceral pode estar associada a outras vias de transmissão tais como transfusional, congênita, ou mesmo vetorial, sendo os indivíduos com infecção assintomática, potenciais reservatórios. Ademais, a identificação da infecção poderia auxiliar na condução dos pacientes com condições de imunossupressão (HIV, transplante, uso de imunomoduladores) e na avaliação da efetividade das medidas de controle. Neste estudo, foram avaliados clinicamente 149 indivíduos residentes em área endêmica de leishmaniose visceral e realizada a reação em cadeia da polimerase (PCR) gênero-específica, testes sorológicos e teste de Montenegro. Destes, 49 (32,9\%) apresentaram PCR positiva, dos quais nenhum evoluiu com clínica de leishmaniose visceral nos três anos subsequentes. Não houve associação entre o resultado da PCR, dos exames sorológicos e do teste cutâneo. A positividade da PCR em indivíduos da área endêmica estudada não indicou risco de progressão para leishmaniose visceral e também não foi associada à maior positividade dos testes sorológicos.

\section{REFERENCES}

1. Adhya S, Chatterjee M, Hassan MQ, Mukherjee S, Sen S. Detection of Leishmania in the blood of early kala-azar patients with the aid of the polymerase chain reaction. Trans R Soc Trop Med Hyg. 1995;89:622-4.

2. Alborzi A, Pourabbas B, Shahian F, Mardaneh J, Pouladfar GR, Ziyaeyan M. Detection of Leishmania infantum kinetoplast DNA in the whole blood of asymptomatic individuals by PCR-ELISA and comparison with other infection markers in endemic areas, Southern Iran. Am J Trop Med Hyg. 2008;79:839-42. 
SILVA, L.A.; ROMERO, H.D.; FAGUNDES, A.; NEHME, N.; FERNANDES, O.; RODRIGUES, V.; COSTA, R.T. \& PRATA, A. - Use of polymerase chain reaction for the diagnosis of asymptomatic Leishmania infection in a visceral leishmaniasis-endemic area. Rev. Inst. Med. Trop. Sao Paulo, 55(2): 101-4, 2013.

3. Assis TS, Braga AS, Pedras MJ, Oliveira E, Barral A, de Siqueira IC, et al. Multi-centric prospective evaluation of rk39 rapid test and direct agglutination test for the diagnosis of visceral leishmaniasis in Brazil. Trans R Soc Trop Med Hyg. 2011;105:81-5.

4. Bhattarai NR, van der Auwera G, Khanal B, de Doncker S, Rijal S, Das ML, et al. PCR and direct agglutination as Leishmania infection markers among healthy Nepalese subjects living in areas endemic for Kala-Azar. Trop Med Int Health. 2009;14:404-11.

5. Boelaert M, Dujardin JC. Diagnostic PCR with Leishmania donovani specificity. Trop Med Int Health. 1999;4:789.

6. Costa CHN, Gomes RBB, Silva MRB, Garcez LM, Ramos PKS, Santos RS, et al. Competence of human host as a reservoir for Leishmania chagasi. J Infect Dis. 2000;182:997-1000.

7. Das VNR, Siddiqui NA, Verma RB, Topno RK, Singh D, Das S, et al. Asymptomatic infection of visceral leishmaniasis in hyperendemic areas of Vaishali district, Bihar, India: a challenge to kala-azar elimination programmes. Trans R Soc Trop Med Hyg. 2011;105:661-6.

8. Garcia-Garcia JA, Martin-Sánchez J, Gallego M, Rivero-Roman A, Camacho A, Riera $\mathrm{C}$, et al. Use of noninvasive markers to detect Leishmania infection in asymptomatic human immunodeficiency virus-infected patients. J Clin Microbiol. 2006;44:4455-8.

9. Ibrahim ME, Lambson B, Yousif AD, Deifalla NS, Alnaiem DA, Ismail, A et al. Kala-azar in a high transmission focus: an ethnic and geographic dimension. Am J Trop Med Hyg. 1999;61:941-4.

10. Lachaud L, Dereure J, Chabbert E, Reynes J, Mauboussin JM, Oziol E, et al. Optimized PCR using patient blood samples for diagnosis and follow-up of visceral leishmaniasis, with special reference to AIDS patients. J Clin Microbiol. 2000;38:236-40.

11. Lachaud L, Chabbert E, Dubessay P, Reynes J, Lamothe J, Bastien P. Comparison of various sample preparation methods for PCR diagnosis of visceral leishmaniasis using peripheral blood. J Clin Microbiol. 2001;39:613-7.

12. Martin-Sanchez J, Lopez-Lopez MC, Acedo-Sanchez C, Castro-Fajardo JJ, Pineda JÁ, Morillas-Marquez F. Diagnosis of infections with Leishmania infantum using PCRELISA. Parasitology. 2001;122:607-15.

13. Martin-Sanchez J, Pineda J, Morillas-Marques F, García-García CA, Acedo C, Macias J. Detection of Leishmania infantum kinetoplast DNA in peripheral blood from asymptomatic individuals at risk for parenterally transmitted infections: relationship between polymerase chain reaction results and other Leishmania infection markers. Am J Trop Med Hyg. 2004; 70:545-8.

14. Michel G, Pomares C, Ferrua B, Marty P. Importance of worldwide asymptomatic carriers of Leishmania infantum (L. chagasi) in human. Acta Trop. 2011;119:69-75.

15. Moreno EC, Gonçalves AV, Chaves AV, Melo MN, Lambertucci JR, Andrade ASR, et al. Inaccuracy of enzyme-linked immunosorbent assay using soluble and recombinant antigens to detect asymptomatic infection by Leishmania infantum. PLoS Negl Trop Dis. 2009;3:e536.
16. Moreno EC, Melo MN, Lambertucci JR, Serufo JC, Andrade ASR, Antunes CMF, et al. Diagnosing human asymptomatic visceral leishmaniasis in an urban area of the State of Minas Gerais, using serological and molecular biology techniques. Rev Soc Bras Med Trop. 2006;39:421-7.

17. Nuzum E, White F $3^{\text {rd }}$, Thakur C, Dietze R, Wages J, Grogl M, et al. Diagnosis of symptomatic visceral leishmaniasis by use of the polymerase chain reaction on patient blood. J Infect Dis. 1995;171:751-4.

18. Osman OF, Oskman L, Ziljstra EE, Kroon NCM, Schoone GJ, Khalil TAG, et al Evaluation of PCR for diagnosis of visceral leishmaniasis. J Clin Microbiol. 1997;35:2454-7.

19. Osman OF, Oskman L, Ziljstra EE, El-Hassam AM, el-Nalim DA, Kager PA. Use of polymerase chain reaction to asses the success of visceral leishmaniasis treatment. Trans R Soc Trop Med Hyg. 1998;92:397-400.

20. Piarroux R, Gambarelli F, Dumon H, Fontes M, Dunan S, Mary C, et al. Comparison of PCR with direct examination of bone marrow aspiration, myeloculture, and serology for diagnosis of visceral leishmaniasis in immunocompromised patients. J Clin Microbiol. 1994;32:746-9.

21. Prata A. Cura parasitológica do calazar. Hospital. 1957;51:571-7.

22. Romero HD, Silva LA, Silva-Vergara ML, Rodrigues V, Costa RT, Guimarães SF, et al. Comparative study of serologic tests for the diagnosis of asymptomatic visceral leishmaniasis in an endemic area. Am J Trop Med Hyg. 2009;81:27-33.

23. Salotra P, Sreenivas G, Pogue GP, Lee N, Nakhasi HL, Ramesh V, et al. Developmen of a species-specific PCR assay for detection of Leishmania donovani in clinical samples from patients with kala-azar and post-kala-azar dermal leishmaniasis. J Clin Microbiol. 2001;39:849-54.

24. Silva LA, Romero HD, Prata A, Costa RT, Nascimento E, Carvalho SF, et al. Immunologic tests in patients after clinical cure of visceral leishmaniasis. Am J Trop Med Hyg. 2006;75:739-43.

25. Silva LA, Romero HD, Nogueira Nascentes GA, Costa RT, Rodrigues V, Prata A Antileishmania immunological tests for asymptomatic subjects living in a visceral leishmaniasis-endemic area in Brazil. Am J Trop Med Hyg. 2011;84:261-6.

26. Smyth AJ, Ghosh A, Hassan MDQ, Basu D, De Bruijn MHL, Adhya S, et al. Rapid and sensitive detection of Leishmania kinetoplast DNA from spleen and blood samples of kala-azar patients. Parasitology. 1992;105:183-92.

27. Zijlstra EE, El-Hassan AM. Leishmaniasis in Sudan. 3. Visceral leishmaniasis. Trans R Soc Trop Med Hyg. 2001;95(suppl. 1):27-58

Received: 6 March 2012

Accepted: 5 September 2012 